\title{
article TRIPLE IDENTITY IN CONFLICT: \\ ethnography in legislative media and its possibilities
}

CRISTIANE BRUM BERNARDES

CEFOR/ Câmara dos Deputados, Brasilia - Distrito Federal - Brazil

ORCID: 0000-0001-5367-3047

SARAH NUNEZ

CEFOR/ Câmara dos Deputados, Brasilia - Distrito Federal - Brazil

ORCID: 0000-0003-0052-4915

DOI: 10.25200/BJR.V17N2.2021.1395

Received in: January $18^{\text {th }}, 2021$

Desk Reviewed: February ${ }^{\text {st }}, 2021$

Desk Review Editor: Fábio Pereira

Revised on: March 3rd, 2021

Approved on: April $4^{\text {th }}, 2021$

\begin{abstract}
This article analyzes the challenges, obstacles, and theoretical and methodological advances that the ethnography of organizations can bring to journalism research based on two studies on legislative media in the Brazilian National Congress. It discusses how the triple identity of ethnographer-journalist-public servant complicates the analysis of these media outlets, creating an environment favorable to reflexivity. Based on the assumption that such media are a privileged space to observe the relationship between the political and journalistic fields, this study concludes that the ethnography advantages are related to the possibility of perceiving and understanding the hybrid identity of the observed subjects, and the researchers themselves. The political role of actors in this context is complex and emphasized in order to further the understanding of the social role of journalism.
\end{abstract}

Keywords: Journalism ethnography. Newsmaking. Legislative media. Public communication. Brazillian National Congress. 


\title{
TRIPLA IDENTIDADE EM TENSÃO: as possibilidades da etnografia em mídias legislativas
}

\begin{abstract}
RESUMO - Este estudo analisa desafios, obstáculos e avanços teóricos e metodológicos que a perspectiva da etnografia das organizações pode trazer à pesquisa em jornalismo, com base em duas análises das mídias legislativas do Congresso Nacional. Discute-se como a tripla identidade de etnógrafa-jornalistaservidora pública complexifica as análises sobre esses veículos, criando um ambiente favorável à reflexividade. Partindo do pressuposto de que tais mídias são um espaço privilegiado para observar a relação entre os campos político e jornalístico, o estudo conclui que os ganhos da etnografia estão relacionados à possibilidade de perceber e compreender a identidade híbrida dos sujeitos observados, e do próprio pesquisador. No contexto estudado, o papel político dos atores é complexificado e colocado em evidência, o que amplia a compreensão do papel social do jornalismo.
\end{abstract}

Palavras-chave: Etnografia do Jornalismo. Newsmaking. Mídias Legislativas. Comunicação Pública. Congresso Nacional.

\section{TRIPLE IDENTIDAD IN TENSIÓN: etnografía en medios legislativos y sus posibilidades}

RESUMEN - Este estudio aborda desafíos, obstáculos y avances teóricos y metodológicos que la perspectiva de la etnografía de las organizaciones puede aportar a la investigación en periodismo, a partir de dos análisis de los medios legislativos del Congreso Nacional brasileño. Se discute cómo la triple identidad de etnógrafo-periodista-servidor público compleja el análisis de estos vehículos, creando un ambiente favorable a la reflexividad. Partiendo del supuesto de que dichos medios son un espacio privilegiado para observar la relación entre los campos político y periodístico, el estudio concluye que las ganancias de la etnografía están relacionadas con la posibilidad de percibir y comprender la identidad híbrida de los sujetos observados y del propio investigador. En el contexto estudiado, se compleja y resalta el rol político de los actores, lo que amplía la comprensión de la función social del periodismo.

Palabras clave: Etnografía del Periodismo. Newsmaking. Medios legislativos. Comunicación pública. Congreso Nacional de Brasil.

\section{Introduction}

This article aims to reflect on the challenges, obstacles, and theoretical and methodological advances that the ethnography of organizations can bring to journalism research. Our reflections are based on two studies on the legislative media in the Brazilian National Congress. These studies were conducted over approximately a decade, between 2006 and 2010 (Bernardes, 2010), and 2018 and 2020 (Nunez, 2020). The first study addressed the four legislative media in the Chamber of Deputies that existed at the time - Jornal, Agência, TV e Rádio Câmara - while the second focused on the process of media convergence in the Senate over the past 12 years with the Portal Senado Notícias. 
Before moving forward, it is important to understand that the Brazilian National Congress is bicameral, composed of the Chamber of Deputies (513 members) and the Federal Senate, where each state has a representation of three elected Senators, a total of 81 Senators. Both houses have organizational structures and independent budgets.

Both legislative houses have sophisticated communication structures, installed in the 1990s, which distribute information about the parliament through radio, television, an online news agency, and a newspaper. These legislative media are funded entirely by the houses, and their professionals (mostly journalists) are selected through public tenders and are afforded employment stability as civil servants. In addition to these civil servants, the legislative media also uses specialized labor for the technical and operational side of its broadcasting. These specialists are either hired from third-party companies or are indicated by parliamentarians or party leaders (Special Nature Positions).

The study on the media forms in the Chamber of Deputies analyzed three specific cultures (journalistic, institutional, and political) and how they influence the production of information on these media forms. The study on the Federal Senate's news portal, on the other hand, focused on the level of public engagement it achieves through its news distribution. Both studies focused on public servants who had competed in public procurement processes and are now stable employees of the institutions.

Despite having different objectives, both surveys discussed the role and identity of professionals working in these media forms and their dual professional status as journalists and civil servants in a legislative institution. This was realized through 59 semi-structured interviews conducted with professionals from Communication departments in the two legislative houses, documentary research, and participant observation over a three-year period for the Chamber of Deputies and a two-year period for the Senate'. Both researchers recorded their daily observations in field diaries, essential for collecting data and analyzing research categories.

Both studies were conducted by researchers in the field of observation and look at the ethnographic perspective of journalism in order to understand the culture of the professionals and the meaning produced by the journalistic activity performed in structures known as source media (Sant'Anna, 2008). Both studies, therefore, follow traditional journalism studies focusing on the production routines of 
news organizations that began with the research of Gaye Tuchmann (1983, 1993) and authors such as Schlesinger (1978), Breed (1993), and Travancas $(1993,2010)$, in what has more recently been called the "first wave of media ethnographies" (Schlesinger, 2015; Jordaan, 2020).

The two studies we used as a basis for this reflection are part of a more recent set of studies dedicated to understanding the changes that have been occurring to newsrooms in the 21 st Century, such as those by Neveu (2006) and Bird (2010), among many others, who dedicate themselves to what is conventionally called Newsmaking Studies (Wolf, 1995) or the "second wave of media ethnographies" (Wahl-Jorgensen, 2010; Schlesinger, 2015; Jordaan, 2020; Robinson \& Anderson, 2020).

We have already contended (Bernardes, 2013, p.664) that legislative media is an important place from which to observe relations between the political and media fields. Professionals in these fields are required to adopt a hybrid identity: while they maintain journalistic values, largely because of their training and previous professional experiences, they are also public servants in a legislative institution; bureaucrats of the Legislative Power that work in the production and dissemination of public and official information.

Every journalist, manager, and publisher is a political actor, but due to the hybrid nature of the legislative media, they are forced to deal more intensely with political issues than they would in the private media, which is a bit of a challenge to their identities. One of the reasons for this is that these media manage the institution's official discourse. As this is a political institution, the discourse, in addition to being journalistic, is political. While it is true that their jobs as journalists and civil servants require them to be impartial and impersonal - professionals in legislative media face the internal political pressures that come with a Legislative House on a daily basis.

The discourse that emerges from the legislative media in the aforementioned studies (Bernardes, 2010; Nunez, 2020) exemplifies the contradictions that its enunciators experience and this may be why these studies focus on the hybrid nature of working with journalism in the Chamber of Deputies and the Federal Senate. Thus, the "ethnographer-civil servant-journalist" of legislative media, with their triple identity, is obliged to reflect on their political role, which is not something journalists in commercial media always do.

In this context, ethnography provides more details of the close relationship between the fields of journalism and politics 
as it seeks to "examine the nature of the media's power and how decisions are mediated by organizations to demystify the demands for professionalism and objectivity made by journalists and reveal how the news market is structured" (Schlesinger, 2015, p.24). By dealing with these relationships, ethnography adds complexity to the studies of legislative media and makes researchers reflect on their role as social scientists and public servants, in addition to their role as communicators. One of the advantages of ethnography is that it allows one to observe what professionals actually do, and not just what they say they do (Jordaan, 2020, p.3).

It is important to note that the ethnographic perspective adopted in this paper is in line with what Peirano (2014, p.385) accentuates as the need for good ethnography: "to go beyond common sense as far as the use of language goes". Thus, we do not merely adopt a referential view of language as an instrument to simply describe reality, but we believe, like the author does, that "fieldwork is done through lived dialogue, which is then revealed through writing" (p.385). As she points out: "words do things, bring about consequences, perform tasks, communicate, and produce results. And words are not the only means of communication: silence also communicates" (p.385).

We shall thus look at how the ethnographic perspective can be applied to journalism studies and what opportunities for reflection on information production are in this process.

\section{Political culture and journalistic culture}

The legislative media have an organizational culture that structures them as newsrooms and, at the same time, bureaucratic bodies in a broader meaning, but that is essentially linked with the way of financing of the activity.

We know that all news organizations have their specific conditions for producing journalism discourse. For Travancas (2010), even though objectivity, clarity, and accuracy are essential rules in the news, the conditions for producing journalism discourse are not neutral, socially or culturally speaking, and a journalist's identity is built in a mix of different social fields: "a journalist's experiences have ambiguities and contradictions. One cannot think of identity as being only conscious, linear trajectories and projects" (Travancas, 2010, 
p.85). Likewise, Bird points out that the news is received socially as a reflection of reality, even though it is a "cultural construction that is formed from narrative conventions and routine practices" (Bird, 2010 , p.5).

Reflecting on studies that Brazilian Anthropology conducts in the political field, Kuschnir (2005, p.10) defines political culture as the "set of attitudes, beliefs, and feelings that give order and meaning to a political process, highlighting the rules and assumptions on which the behavior of social actors is based". Based on this definition, we can imagine the legislative media as an institutional space where political and journalistic cultures meet. This encounter produces action and discourse strategies specific to the agents that are inserted within them.

While journalists are commonly referred to as "mediators", Kuschnir (2005, p.9) also points out that "parliamentarians act as fundamental mediators between different levels of culture; they are translators of the values, projects, and dramas between the population and the public power". In their professions, politicians and journalists work with the explanation of things and the production of speeches (Bourdieu, 2005), disputing what the author calls symbolic power. On one hand, they strive to explicitly define practical principles of perspectives and division of the world. On the other hand, they struggle to "[...] establish these principles of perspectives and division as legitimately recognized categories for the construction of the social world" (Bourdieu, 2005, p.37).

If legislative media is a space of conflict between the journalistic and political fields (Bernardes, 2013, p.682) then those who work in those fields must experience many inconsistencies with their identities, as mentioned in a number of works (Barros, 2019; Bernardes, 2008, 2013, 2015; Gonçalves, 2010, 2015; Queiroz, 2007). Some of these authors believe source media work in the legislative houses forms a new professional identity: the legislative journalist (Gonçalves, 2010). Others describe this activity as being hybrid, a mixture of journalism with institutional dissemination (Queiroz, 2007). Bernardes (2010) believes that the informative nature of legislative media is primarily a conflicting one between the concepts of political, institutional, and political communication. These differing normative views influence what parliament news is and what it should be.

Unlike journalists in conventional media (they are outside agents whose access to Parliament is controlled) legislative 
journalists are a part of the parliamentary makeup. If conventional media journalists go into parliament looking for scandals, acting as entrepreneurs of the "moralization of politics", then the insider professionals "are there to act as entrepreneurs of the good reputation of legislative houses" (Barros, 2019, p.74), with an objective that involves specific political and professional values.

Barros (2019) highlights the political objective of the legislative media servant, while Bernardes (2013) emphasizes the impact that values of public communication have and a likely consensus on theoretical conceptions, parliamentary debate, and professional discourse on a concept of democracy which upholds the view that information about representative institutions is highly important for the public. Thus, legislative journalists claim that the demand for credibility is even greater for legislative media because of its institutional nature as an official source of information for other vehicles (Bernardes, 2015). In other words, having neutral reports is an important "logistical condition" for working in parliament (Bernardes, 2015, p.73) since the political actors have a direct influence on the media managers, who themselves are servants to the hierarchy of the legislative house and its political direction.

Despite occasional disagreements and differing focal points, there are several studies analyzing media forms that are maintained and financed (particularly in Brazil) to disseminate journalistic narratives about parliament and the legislative process and how they are structured similarly to newsrooms. One point of interest is the fact that the legislative media does not have any commercial objectives, which eliminates the conflict identified by Traquina (2001) in the traditional news media. In this perspective, journalists from the legislative media are not subjected to the economic pressures so frequent in commercial media newsrooms, and they also fervently criticize the criteria of newsworthiness adopted by the commercial media, which is often accused of not allowing for the plurality of views needed for good journalistic practice (Bernardes, 2015).

However, this does not mean that there are no conflicting pressures on legislative news media. The dual status of parliamentarians acting as sources of information for and hierarchical superiors (or publishers) of journalists poses important challenges to professional work (Bernardes, 2011). Some of the specific features of the legislative media's political-institutional nature are: media 
agendas are subject to the legislative agenda; narratives are mainly concentrated within the National Congress, where most of the reported facts take place; the concerted number of statements from official sources; the lack of journalists' positions regarding the events they cover; and the lack of any behind-the-scenes or off-the-record comments and rumors to support the articles, a common practice in traditional journalism.

In any case, the absence of commercial objectives for legislative media suggests an identity built much more around the idea of public service, especially because said service is carried out by an institution representative of democracy. In this sense, the ethnography of these media forms provides a good opportunity to analyze the private world of a public institution (Schlesinger, 2015). In other words, the ethnographies presented in this article deal with the internal politics of an organizational bureaucracy whose purpose is to produce information on parliament.

What are the values that journalists working in the legislative media based on? Do they practice political journalism or civic journalism? Are they merely press officers? Are they simply disseminators of information? We are not too interested in defining the status of this information production, but rather in arguing about the validity of the ethnographic perspective-which Neveu (2006) claims is more than just a method for collecting data, and Peirano (2014) does not constitute as just a "method"-to understand the work of these professionals.

In this sense, legislative media is an important space from which to study the political performance of journalists, including their work as bureaucrats in a political institution. As we mentioned earlier, all journalists act as political actors even though the deontology of the profession hides their positions when constructing objective narratives. Legislative media make this position very clear as the identity conflicts which journalists are exposed to are made more apparent. They need to combine their professional identity with the identity of a public servant, which also carries with it the ideal of impartiality and impersonality as important values.

We shall now look at how the ethnographic method helps to understand this phenomenon. 


\section{Ethnography in the Brazilian National Congress media}

The studies mentioned here are interpretative case studies as they do not only describe how the Chamber of Deputies media work and the changes to the Portal Senado Notícias. Godoy describes the interpretive case study as one that seeks patterns in the data and develops "conceptual categories that make it possible to illustrate, confirm or oppose theoretical assumptions" (Godoy, 2010, p.124). A study is thus ethnographic if it develops research and a "dense" description - in Geertz's (1973) terms - of culture, with particular attention to the social structures and behavior of individuals as members of the group. However, for Godoy, the use of ethnographic techniques alone, such as participant observation, in-depth interviews, and field diaries, does not guarantee ethnography.

To understand the functioning of communication vehicles in the Chamber of Deputies, Bernardes (2010) analyzes the newsmaking conditions of these media. To do this, she spent five months working as a reporter for Rádio Câmara (from August to December 2008) and seven more months working as a staff editor and text editor at TV Câmara (from May to November 2009). Before this, she worked as a reporter for the Agência Câmara since 2005, when the research was initiated.

Her decision to adopt the ethnographic methodology was facilitated by her time working as a civil servant, with a regular contract, in the Chamber of Deputies. As a journalist employed by the Chamber, she saw her professional activity as an opportunity for observation work, for reasons similar to those proposed by Schlesinger (2015, p.28), who mentions the importance of performing a "solo ethnography" and the insights that can be obtained through doing so.

Some of the initial categories that Bernardes (2010) established were a plurality of sources, subjects and opinions, usefulness, accuracy and credibility of information, and a respect for democratic values. During her data collection, however, she realized that "such categories were much more related to a normative ideal of public communication - as defined by some authors - than to a practice perceived in the vehicles" (Bernardes, 2010, p.46).

About halfway through her empirical research, Bernardes began to base her observations on dichotomies identified in the practice and discourse of social actors. She observed conflicting 
relationships in the Chamber's communication vehicles such as the tension between the standard of the commercial press and the normative rules of public communication, between political officials and technical staff, between members of the bureaucracy, and between the complexity of politics and the simplification of journalism. For Bernardes, the political, journalistic, and institutional cultures, although different, merge in the day-to-day activities of these legislative media.

The second study, which analyzed the changes to the Portal Senado Notícias between the years 2009 and 2020, aimed to discover "what kind of arguments professionals from the Senate's Communication Secretariat [Secom] have towards the convergence of the TV Senado, Rádio Senado, and Agência Senado media on the Portal Senado Notícias" (Nunez, 2020, p.17). She was interested in the justifications, the wins, and losses that these social actors saw in this media convergence, with its varied content formats distributed by the Portal including audio, video, and infographics, in addition to text and photo.

From an internal perspective, Nunez (2020) sought to understand if and to what extent the culture (behavior, beliefs, opinions, and strategies) of Secom professionals is consistent with Leston-Bandeira's argument $(2014,2016)$ that Legislature should promote public engagement. In this case, however, the fact that she was chief editor of the Portal Senado Notícias throughout her research period helped bring a manager's perspective to her research.

The objective of her study on the Senate was to "1) understand the culture of the communication professionals involved in the meaning process and 2) to interpret the meanings of certain events to the culture of the group, so an ethnographic case study has been performed" (Nunez, 2020, p.60). Two analytical categories were initially defined by the researcher to accomplish this: 1) convergence, as a possible form for framing the changes to the portal over the last 12 years, and; 2) the promotion of public engagement, as something that should guide legislative communication due to its public character.

Like Bernardes, Nunez discovered throughout her research that normative principles - especially regarding public communication - were not sufficient to understand the studied phenomena. The issues of "natives" identifying with the more general values of the journalistic field (including private) were fundamental in the object, 
as were the conflicting and tense relations as ways of providing good windows through which to observe the objects of the two studies.

In addition to public engagement as a guide for legislative communication, Nunez (2020) initially defined the convergence standard in order to frame the changes to the news portal over the last 12 years. But the fieldwork uncovered other analytical categories, such as "framing the changes to the site in terms of needing to follow trends in the private media market and framing the Senate Communication as a field of mutual resistance between the vehicles" (p.62).

The relevance of researching the theme "was to shed light on changes that only represent the majority choice for the journalistic model of communication in public institutions" (Nunez, 2020 , p.8). The study concludes that the self-image of Senate media professionals as news producers, although not consensual, hinders the development of a more relational communication between the public and the institution.

Both these experiences are echoed in Aspers and Corte (2019) when they state that by being so close to their data for a long time - whether images, texts, or human interactions - qualitative researchers (including ethnographers) are encouraged to continually test their theories and assumptions; testing these hypotheses in the face of "reality" usually takes the research in new directions.

\section{Reflexivity in triple identity}

In order to describe significant events for a group, where the focus is on the meaning of these events for the culture of said group, ethnography uses fieldwork that involves intense contact over an extended period with the subjects so that the researcher can "discover how a given network of meanings is organized" (Godoy, 2010, p.125). Because of this close contact with groups over a relatively long period, the researcher, according to Kuschnir (2005), needs to design strategies so as not to bring any preconceived ideas of power and politics that that researcher may have learned from his or her own society into that field. Since anthropological invisibility is idealistic, Kuschnir (2005) reasons that the researcher cannot obtain neutrality in the description, but can reflect on personal positions and identities.

In a classic reflection on the work of ethnographers in contemporary urban societies, Velho (1981) emphasizes that 
reflexivity of environments that are known to the researcher involves denaturalizing the meanings that we attribute to social practices so that the meanings attributed by the subjects we observe can be seen. As Da Matta (1978, p.5) also points out, "the problem, then, is to lift the cover off a member of a class and a specific social group in order to be able - as an ethnologist - to discover some common social rule and then find [...] the exotic that is rooted within us by reification and legitimation mechanisms".

In that regard, ethnography in organizations, which includes the ethnography of journalism, can be carried out by internal researchers, provided that the movement recommended by $\mathrm{Da}$ Matta (1978) and Wahl-Jorgensen (2010) can occur - changing the common to exotic -, which involves an emotional detachment from the observed social practices. For the author, ethnography "turns toward our own society, similar to a self-exorcism" (Da Matta, 1978, p.5) leaving behind the classic tradition of anthropology to pursue different cultures.

Peirano (2014, p.379) highlights that this epistemological movement of "strangeness" is quite complex and makes the ethnographic process more fluid than most other theoretical perspectives, especially since field research "does not have any official start or end time" when it comes to looking at our cultural communities.

\begin{abstract}
These moments are arbitrary by definition and, since we have abandoned great voyages to isolated and exotic islands, they depend on the potential for strangeness, on the unusual of the experience, on the need to examine why some events, lived or observed, surprise us. And that is how we become agents in ethnography, not just as researchers, but as natives/ethnographers. This dimension questions ethnography as a method. The central question being: where and when did we learn that "strangeness" is a fundamental tool in anthropological research? And what does this strangeness mean? (Peirano, 2014, p.379).
\end{abstract}

In studies by Bernardes (2010) and Nunez (2020), this strangeness is more profound because, in addition to the interpretations provided by professionals from the two communication departments about the processes under analysis, there is also a second interpretation at work: how the researchers understand the speech - and the interpretation - of the actors in the field. These are studies resulting from a double interpretation, or meta-interpretation, on the phenomenon.

Specifically related to ethnographic research, Lago (2007, p.62) highlights that the double state of the researcher (a journalist 
researching journalism) does not prevent the research from being carried out, but it does need to be considered when choosing the theoretical-methodological options so as to create the conditions of "suspicion" necessary for the study, that is, "the art of research requires a common suspicion of what is said and shown and, mainly, of what we come to say" (Lago, 2007, p.63). Ethnography reveals how professionals are socialized in a shared identity, approaching journalism as a "living experiment", as established by Jordaan (2020, p.13).

Bird (2010), in turn, highlights the similarities between a journalist's and an ethnographer's activities since both try to obtain information from people and build narratives about what they have learned for their audiences. In this sense, the epistemological exercise of ethnography, trying to describe the world from the "natives' points of view" (Bird, 2010, p.4) is complex because the researchers themselves are "natives" to the journalistic field and, at the same time, they are public servants of political institutions that are not dedicated to journalism.

For this reason, we emphasize the genuine triple state of researchers in legislative media: journalists and public servants researching legislative media. In a way, the reflexivity advocated by authors of anthropology is commonplace for many professionals in the legislative media since they need to deal with - and reflect on - their hybrid identity as journalists and public servants: press advisers, content producers, political communicators, bureaucrats, and all the nuances that may come with holding a position in a parliamentary institution.

Ethnographic research in legislative media, therefore, poses extra challenges to the institutions' internal researchers because, in addition to the two conflicting professional identities in the ethnography of journalism - journalists and researchers -, these internal researchers are also public servants. Add this to the fact that, in qualitative research, the researcher is the primary instrument for data collection and analysis in an inductive research strategy (Merriam \& Grenier, 2019) which requires continual criticism and adjustments to be made to research processes.

All of this implies an in-depth reflection on the political position occupied, both in the broadest sense and in the sense related to internal disputes within the legislative institution. A process that can ultimately challenge the prejudices and preconceptions researchers have about their professional practices and the research experience itself. In a broader outlook, the ethnographies of journalism debate 
how "truth is defined and contested in a world in which control of information means power" (Bird, 2010, p.14).

Both these authors confirmed in their studies that normative principles are not enough to understand the studied phenomena. Identifying "natives" with more general values in journalism (mainly commercial journalism) and particularly the conflict between media vehicles from the same institution are aspects of journalism observed in both studies to have brought about changes to the analytical categories, as explained previously.

Next, we shall look at the main advantages and practical obstacles for adopting ethnography in legislative media studies and how it relates to the construction of this triple identity: journalistcivil servant-ethnographer.

\subsection{Data access: problematic or convenient?}

Some important aspects for defining the methodology are "data access, specific knowledge of technical, professional and organizational matters, and attention to the production timing of the company under analysis" (Newcomb, 1993, p.125). As Newcomb states (1993), a well-informed researcher has advantages when observing, which is not so restricted to the information and explanations provided by the producers. For this author, the strength of the method is rooted in the effective observation of the process.

According to Bernardes (2010), the ethnography on the conditions of news media production in the Chamber of Deputies was facilitated by her status as a public servant for the institution. Bernardes believes that her position as a journalist for the media forms provided an important opportunity for observation. After all, as Jordaan (2020, p.6) points out, ethnographic methods allow a researcher "to get very close to a group in order to describe their practices, routines and cultural norms".

Some other advantages native researchers have highlighted by Jordaan (2020) are a better understanding of the practices observed, encouraging more openness from insiders, and greater trust from those insiders that the researcher will not release or publish any confidential information that may be exchanged. The researchers, as employees of the institution, are limited in terms of what they can publish about their colleagues and bosses, which 
may provide insiders with a greater sense of security regarding their collaboration.

Despite the relative ease of access to the field and the greater openness of informants, the fact that Bernardes was a Secom journalist created a series of obstacles for her. As Morley and Silverstone (1993, p.187) point out, in the ethnographic method "the researcher is an active participant in the research process and, therefore, it is necessary to take extra care with reflexivity to avoid partiality".

According to Bernardes, her role as an observer was frequently questioned because she was a native member of the community she was observing. In general, the "naturalization of the practices and justifications given by the actors for their daily activities is one of the dangers faced by researchers in this kind of position" (Bernardes, 2010 , p.47). The author says that her point of view as a journalist determined much of her observations. One problem with this could be with "the degree of familiarity with the object, which can restrict knowledge if the observer's position is not relativized and an object of systematic reflection" (Velho, 1981, p.128).

"Only with constant reflexivity can one avoid the knowledge compromised by the habits, routines, and stereotypes within it" (Bernardes, 2010, p.48). For this author, this bias was reduced because she had changed media vehicles during her research period which she believed led to not only a modification in daily work routines and the physical environment but also the exchange of experiences with different Secom groups in the Chamber of Deputies, leading to some awkward moments and the need to re-organize the networks of insiders throughout the process.

\begin{abstract}
The beginning of each period on Radio and TV was surrounded by anxiety and expectation, in addition to establishing new personal and work relationships that also influenced the perception of the structure and routines in the media vehicles. In some form, writing in the field diary was a way to relieve some anxiety, in addition to reflecting on reality and being an instrument for data collection. Going to TV Câmara was especially difficult from a professional and personal point of view. With little experience in television, I faced a lot of opposition from the team. I did not know very many people from TV and, as soon as I arrived, I was labeled a "friend of the boss" because I had previously worked with the station's director, which made it difficult to contact many professionals at the station, especially those who held higher-ranking positions. (Bernardes, 2010, pp. 49-50).
\end{abstract}

Over the course of her research, Bernardes (2010) was seen as a colleague, a friend, an invader, a spy, a spokesperson, and a psychologist 
by the actors in the field, a similar situation that Jordaan (2020) had experienced in ethnography. Bernardes relates that she identified more with the group of reporters and that her view, in this case, was conditioned by the lower position in the hierarchical rank structure of the newsroom and the media vehicles' bureaucratic organizations.

In the study conducted on the Senate, Nunez (2020) highlights a reasonably different condition with other possible implications for his ethnographic analysis: being the manager of the Portal Senado Notícias and the influence this position has on the 16 qualitative interviews conducted in the fieldwork.

\begin{abstract}
[The influence] cannot be ruled out and could occur on two main fronts: in the generation of data with the professionals at the Portal Notícias, hierarchical, functional, and managerial questions could influence responses from both superiors and subordinates. Regarding the interviewees from areas with no hierarchical connection, especially other vehicles such as TV and Radio, criticisms of the integration process that is, in part, coordinated by the Portal, could be avoided to maintain healthy work relations. (Nunez, 2020, p.67).
\end{abstract}

To mitigate these risks, Nunez (2020) always introduced herself as a researcher when requesting interviews. She repeated this information at the beginning of the interviews, explaining the purpose of the meeting and ensuring the anonymity of the information. She also says that, for the interviewees to feel more comfortable when expressing their opinions, the interviews were not conducted in newsrooms; instead, they were conducted in more reserved places like the media vehicle's meeting rooms.

On the other hand, Bernardes' identification with reporters facilitated her access to the field but made it more difficult to gain access to institutional decisions made behind the scenes. The author explains that "the strategy of conducting in-depth interviews with managers and analyzing the material produced by Secom were ways to minimize this limitation" (Bernardes, 2010, p.51). Nunez (2020), who had more contact with the managing group, had more access to toplevel meetings and other decision-making forums. The technique used to approach other groups, such as reporters and producers who did not hold any management positions, was to conduct in-depth interviews.

As Newcomb (1993, p.127) states, "the interviews provide views from several perspectives on the data and themes related to the practice". For this reason, the information provided in interviews, in addition to helping us reconstruct the history of the media vehicles, 
also helped to identify the ideological premises that guide journalism and read the content it communicates. Mostly, the interviews provide access to decisions that researchers might not have been aware of due to their hierarchical ranking within the media vehicles (Bernardes, 2010). The informants' availability and their desire to participate facilitate a researcher's work as it requires less coercion on the part of the researcher to have a dialogue. Perhaps at this point, as Bernardes (2010, p.53) contemplates, "identifying the researcher as a co-worker and the reasonable knowledge that many interviewees had of the research conditions have increased their confidence and encouraged them to speak".

At this point, the researchers' internal viewpoint could provide an additional advantage for reflection on the field. Nunez's (2020) case, who was already pondering the relationship between the media vehicles even before starting her Master's Degree and based on her ten-year experience at Secom in the Senate and unsystematic observation, is exemplary.

The ethnographic observation of the Senate occurred from within, both because the viewpoints investigated were of the Senate Communication employees and because, as already explained, the researcher belonged to this same group at the time the research was being conducted. The position of the observer in the field requires constant approximation and distancing, according to Nunez (2020). At the same time that the appropriation of theoretical knowledge is essential for a critical analysis of the object, and the "strangeness" from familiar perspectives, an ethnographic process considered essential by Peirano (2014) and Jordaan (2020), the reflexivity with the field is fundamental in a study focusing on understanding the values, beliefs, attitudes, and motives of the "natives".

Lago (2007) argues that the application of ethnography in journalism research strays away from the mechanical application of the method and includes the trained eye of anthropology to suspect the research and the role of the researcher conducting the analytical perspective. In other words, one needs to consider that there is a lot of prior idealization cast on the method as if it were possible for a researcher to remove the clothes of his or her own culture and dress in the culture of those he or she observes (Lago, 2007). On the other hand, in situations where the researcher is part of the observed group (a "native", which is common in journalism) the necessary reflexivity goes through the "strangeness of the familiar", in Velho's terms. 
The process of strangeness to the familiar becomes possible once we can confront, intellectually and emotionally, different versions and existing interpretations of the facts or situations. Studying conflicts, disputes, accusations, and moments of discontinuity, in general, is particularly useful since, when focused on social drama, the contours of different groups, ideologies, interests, subcultures, etc. can be registered, allowing for a remapping of the society. (Velho, 1981, pp.131-132).

Journalists who use ethnography to research journalism also need to reflect on how they identify with the values expressed by the group they are studying, a kind of psychoanalytic exercise on their professional activity to denaturalize these values, something that demands a significant amount of research. The fact that this subjective process may be riddled with contradictions is no reason to desist. On the contrary, as Lago argues, 'complicity' with the research object allows us to reveal issues and identify paradoxes that might not otherwise be observed from a distance" (Lago, 2007, p.61).

Returning to the legislative media in the Chamber of Deputies, Bernardes (2010) started her research with a very decisive normative focus on defending greater autonomy for the journalistic field concerning the political field. This normative positioning on the role of journalism in society has a lot to do with her training as a journalist and the profession's deontological discourse. A clearer perception of the political role played by journalists defending the autonomy of the field was structured over the course of her research and brought a number of issues to light.

One of the more important issues was that, in terms of the representative system, journalists are not representatives of political representation, even though they do exercise this role from time to time, often without admitting it. One question (Bernardes, 2013) is why would journalists have complete autonomy to produce political discourse in the contemporary world? What is their dispute with political actors? Another important question is what political role, as civil servants and journalists, do legislative media professionals in the Chamber of Deputies and the Federal Senate play?

While the ethnographic research carried out by Bernardes (2010) begins with a normative focus on the autonomy of the journalistic field, Nunez's research (2020), published ten years later as part of a political science course, incorporates knowledge from works about the Chamber of Deputies media (Bernardes, 2010; Barros et al., 2014; Barros \& Bernardes, 2015). The author uses these works as the basis to question the power of journalism and to promote 
the necessary relational nature of communication between legislative power and the public (Zémor, 2009; Urbinati, 2006).

While the first study advocates for more autonomy for public service journalism in relation to politics, the second demonstrates that politics, as a real demand from citizens, needs journalism for its realization.

Both approaches, although they have undergone some changes throughout the two studies, use ethnography to shed light on social actors' self-images and the relationships established in the legislative media. In fact, understanding this self-image - its values, perceptions, and attitudes - and the relationships are what one uses to answer the research questions. Participant observation and indepth interviews are the most appropriate techniques here and are also used to identify, both individually and relationally, tensions, conflicts, convergences, and divergences in defining strategies and journalistic production.

\subsection{Triple identity: conflict}

The qualitative researcher's position as a primary tool for close observation of cultural production represented by the news leads to discoveries that might not have been made otherwise. Ethnographers, therefore, must first understand themselves before they can understand the world around them (Stewart et al., 2017). In this sense, "learning the rules of the culture of the people studied and learning to interpret events and actions based on these rules" (Morley \& Stone, 1993, p.187) is the central objective of ethnography.

In Bernardes' studies (2010), one of the more important questions was to understand the "mutual relations between media and politics in an institutional environment that extends throughout the two fields. It is also important to ascertain how social practices are justified by the normative discourse of these actors" (Bernardes, 2013, p.672). The main theme was on how people orient themselves - and consequently what the symbolic result of these practical orientations is - within the world of meaning organized by the institutional nature of media vehicles, their power relationships, professional obligations, different guidelines, etc.

According to Neveu (2006, p.75), "paying attention to the routine interactions of newsrooms or the relationships with sources 
is one of the more fruitful means towards understanding the realities of journalistic work". This is based on a detailed observation of information processes and social relations that interfere in production. This makes it possible to analyze how the social actors behave during the process and to observe the relationships that establish between the media and political fields (Bernardes, 2010). For example, Bernardes reports that the issue of political relations in research has never gone unnoticed by interviewees.

I observed certain anxiety among the professionals when addressing the political pressures as if the research work did not deal with any other aspect or issue. Some interviewees even expressed a desire to have the researcher acting as a spokesperson for their criticism and anguish concerning the politics and how it interferes in journalistic production of the Chamber's media. (Bernardes, 2010, p.53).

The profile of journalists suffering from political pressures - those with less time in public service and who did not hold any management positions (Bernardes, 2010) - raises the question of different nuances in professional identities within the legislative media. But mostly, it highlights that the relationship between the journalistic and political fields does not occur only between journalists from the legislative and parliamentary media.

To some extent, mainly from high-level directors at the legislative vehicles, the journalistic field of the legislative media is also a markedly political one, especially since it is part of the bureaucratic structure of a political institution. The higher-ranking position the civil servant holds, the greater the likelihood to be close to parliamentarians which, together with political and institutional issues, can influence their decisions.

Perceptions about the anxieties of civil servants in the face of political pressure, tensions, and other cultural and relational issues, as evidenced in the work of Bernardes (2010), would hardly be detected by other research methods other than ethnography, even qualitative ones. The tension between journalistic values and politicalinstitutional values of legislative media work remains well evidenced in the two surveys; for example, when collecting or generating the opinions of professionals about news criteria in legislative media, whether through participant observation or an interview.

In line with the deontology of the journalistic field, Cook (2011, p.209), for example, states that journalists contribute with 
their specific conceptions of what they believe deserves to be reported on while contemplating their work.

While politicians dictate conditions and rules for access and designate certain events and issues as important by creating an arena for them, reporters can look at this material (and they do) and decide whether something is interesting enough to be covered and then constructed as a coherent narrative. (Cook, 2011, p.209).

Similar opinions are shared by media professionals in the Chamber of Deputies and the Senate. However, some believe that the legislative media should adopt more institution-based criteria as it better serves the public interest. In an interview with Nunez (2020, p.98), a managing journalist states that "it is not possible to judge whether the [legislative] matter under discussion is good or bad, what we need to show is that a discussion is being held, about good topics or bad, from different points of view". This interviewee believes that the "universal coverage" of legislative events (there is at least one news item published on the Portal Senado Notícias for each official legislative activity) creates public interest in the work carried out.

The approximation of more journalistic newsworthy criteria adhering to institutional constraints and rules (as is the case with "universal coverage") is just one example of the many self-images of social actors in legislative media. By analyzing production routines, relations between public servants, and the defense of arguments within legislative media vehicles, ethnography is able to identify the divergences, tensions, and complexities that shape the environment.

By applying a normative character to promoting public engagement between the Senate and the public (researcher), Nunez (2020) is questioning the value of journalistic identity (journalist) for a more participatory and deliberative democracy. While she is fixed (civil servant) on the concerns of her fellow-servants about a communication model (analogic) that may become obsolete, she does ponder about the need to widen the borders of Secom in the Senate to find other models for producing information and integrating content which is more in line with the public interest. The author demonstrates that the principles of public communication are not sufficient to analyze the information produced by the Portal Senado Notícias.

Along similar lines, Bernardes' research (2010) leads to an idea of "detachment" for an identity solely linked to the journalistic field. This author uses ethnography to reach the conclusion that 
legislative media work is a combination of journalistic discourse with institutional communication of a strong political nature (aimed at covering political-legislative activities) and of a public nature (focusing on issues of public interest and the role of political representation).

\section{Discussion}

Using the ethnographic perspective to study journalistic organizations that work closely with politics (the legislative media at the Brazilian National Congress) was the subject of this article. The objective was to reflect on the possibilities, challenges, and practical obstacles that this specific type of research presents. We would like to draw attention to the perspective of Peirano (2014, p.383), according to which ethnography is not a simple "method", but a true "theoretical-ethnographic formulation". So, despite the similarities mentioned earlier between ethnography and journalism (Bird, 2010), ethnography differs from journalism in that it offers further theoretical development about the researched object, going beyond simple curiosity about the social event.

One of the challenges of the internal perspective, observed in both ethnographic works, is the risk that the researcher, who identifies with the subgroup in the organization to which he or she belongs, will take the perceptions of this subgroup and see them as general perceptions for the field. In both studies, the risk was mitigated by conducting in-depth interviews with professionals from many different internal identities; by having activities in different roles and functions, in the case of Bernardes; and by a constant reflection on the researchers' place within the field of observation.

On the other hand, both researchers, belonging to the field, had easy access to documents and participant observation in periods outside those specifically defined for the research. The theoreticalmethodological advantages that ethnography provides also helped in recognizing and understanding the hybrid identity of the observed subjects and of the researchers themselves, from personal and relational experiences and the crossing of "paths of empathy and humility" that being close to the natives makes possible, as emphasized by Da Matta (1978, p.11). Thus, the triple identity of an ethnographer-journalist-public servant has complicated the analysis and expanded its potential for reflexivity. 
The concern that journalists from the Chamber of Deputies have over political pressures - especially those who have spent less time working as a public servant and do not hold a management position (Bernardes, 2010) - is an example of the tensions faced by professionals in the legislative media. "Some interviewees even expressed their wishes to have the researcher be a spokesperson for their criticism of and concerns over politics and how it interferes in the journalistic production of the Chamber's media vehicles" (Bernardes, 2010, p.53).

However, it is important to point out that this intersection between the journalistic and political fields is not unique to journalists from the legislative and parliamentary media. To some extent, mainly at the top levels in an organization, like the board of directors for legislative media, the journalistic field itself becomes distinctly political. The higher the civil servant's level of hierarchy, the greater the chance of not only being close to parliamentarians but also having the weight of political and institutional issues influence their decisions. As we stated at the beginning of this paper, every journalist and every civil servant is a political agent, a relationship which is intensified in legislative media because journalists/civil servants manage the political discourse within and provide official versions of the events that occur within Parliament.

Perceptions about the concerns of civil servants in the face of political pressure, as evidenced in the work of Bernardes (2010); internal political tensions and disputes between sectors, as shown by Nunez (2020); in addition to internal cultural and relational aspects would hardly be detected by other research methods, even qualitative. The conflict between the journalistic and political/ institutional values of legislative media work is well-documented in the two studies, especially with regards to the professionals' opinions about the criteria of newsworthiness and the institutional discourses they produce, either through participant observation or through interviews.

One final point to mention is the fact that both analyses were mainly performed on the structure of information networks within the legislative houses than in actual "journalistic newsrooms". Bernardes examined the experience of different journalist groups who interact with each other in the Chamber of Deputies, while Nunez (2020) analyzed the integration and convergence of what these different groups produced and how it took place in the Federal Senate. Thus, 
both studies strayed from Wahl-Jorgensen's critique (2010) that ethnographic studies focus too much on the hierarchical structures of the newsrooms of large companies since these two studies showed alternative realities to the mainstream media, organized in the form of networks, dispute, and cooperation, no longer in the traditional physical spaces destined for journalists' sociability.

In this sense, ethnography's contribution to the analysis of legislative media and journalism studies, in general, is broad and full of possibilities for developing new realities of practicing journalism, especially the political role that journalists, civil servants, and social scientists perform in their professions.

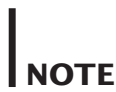

1 It is interesting to note that "entry to the field", in the case of ethnography, can occur even before the research has been formalized, as it begins with the process of "strangeness of the familiar" suggested by the Anthropological Theory.

\section{| REFERENCES}

Aspers, P., \& Corte, U. (2019). What is Qualitative in Qualitative Research. Qual Sociol, (42), 139-160. DOI: 10.1007/s11133-0199413-7

Barros, A. T. (2019). Valores políticos dos jornalistas do Congresso Nacional. Intercom - Revista Brasileira de Ciências da Comunicação, 42(1), 73-91. DOI: 10.1590/1809-5844201914

Barros, A. T., \& Bernardes, C. B. (2015). Dilemas dos sistemas híbridos de comunicação institucional: análise das tensões e dos conflitos no projeto da Câmara dos Deputados. Revista Brasileira de Comunicação Organizacional e Relações Públicas (Organicom), 12(22), 26-37. DOI: 10.11606/issn.2238-2593.organicom.2015.139263

Barros, A. T., Bernardes, C. B., \& Rodrigues, M. R. (2014). O discurso fundador das mídias legislativas da Câmara dos Deputados. E-Legis, 7(14), 7-25. DOI: 10.51206/e-legis.v14i14.184

Bernardes, C. B. (2010). Política, institucional ou pública? Uma reflexão sobre a mídia legislativa da Câmara dos Deputados [doctoral dissertation, Universidade do Estado do Rio de Janeiro]. Rede Sirius: Bibliotecas da UERJ. 
Bernardes, C. B. (2011). As Fontes de Informação nas Mídias Legislativas: oficialismo e diversidade na produção noticiosa sobre a Câmara dos Deputados. Brazilian Journalism Research, 7(1), 32-49. DOI: 10.25200/BJR.v7n1.2011.284

Bernardes, C. B. (2013). Parlamentares $\times$ jornalistas: a dinâmica política das mídias legislativas da Câmara dos Deputados. Revista Sociedade e Estado, 28(3), 663-689. DOI: 10.1590/S01 02-69922013000300011

Bernardes, C. B. (2015). A configuração da identidade profissional dos jornalistas da Câmara dos Deputados. In Z. L. Adghirni (Ed.), Jornalismo e Poder Legislativo: Relações entre mídia e política no Brasil (pp.61-89). Curitiba: Appris.

Bird, E. (2010). The Anthropology of News and Journalism. Global Perspectives. Bloomington: Indiana University Press.

Bourdieu, P. (2005). The political field, the social science field, and the journalistic field. In R. Benson \& E. Neveu (Eds.), Bourdieu and the journalistic field (pp.29-47). Cambridge: Polity Press.

Breed, W. (1993). Controlo social na redacção. Uma análise funcional. In N. Traquina (Ed.), Jornalismo: questões, teorias e estórias (pp.152166). Lisboa: Vega Ltda.

Cook, T. (2011). O jornalismo político. Revista Brasileira de Ciência Política, (6), 203-247. Retrieved from https://periodicos.unb.br/ index.php/rbcp/article/view/1884

Da Matta, R. (1978). O ofício de etnólogo ou como ter Anthropological Blues. Boletim do Museu Nacional, (27), 1-12. Retrieved from www. ppgasmn-ufrj.com/uploads/2/7/2/8/27281669/boletim_do_ museu_nacional_27.pdf

Geertz, C. (1973). The Interpretation of Cultures: Selected Essays. New York: Basic Books.

Godoy, A. S. (2010). Estudo de caso qualitativo. In C.K. Godoi, R. Bandeira-De-Mello \& A. B. Silva (Eds.), Pesquisa qualitativa em estudos organizacionais. Paradigmas, estratégias e métodos ( ${ }^{\text {nd }}$ ed.) (pp. 115 -146). São Paulo: Saraiva,

Gonçalves, R. M. D. L. F. (2010). O superhomem pendura o paletó na repartição: a gênese do jornalista legislativo [master thesis, Universidade de Brasília]. Repositório Institucional da UNB.

Gonçalves, R. M. D. L. F. (2015). Gênese e Perfil do Jornalista Legislativo. In Z. L. Adghirni (Ed.), Jornalismo e Poder Legislativo: Relações entre mídia e política no Brasil (pp.37-59). Curitiba: Appris.

Jordaan, M. (2020). An Open Mind, Not an Empty Head: Towards 
Perpetual Waves of Newswork Ethnography. African Journalism Studies, 41(4), 1-17. DOI: 10.1080/23743670.2020.1785519

Kuschnir, K. (2005). Antropologia da política: uma perspectiva brasileira. Centre for Brazilian Studies, (64), 1-38. Retrieved from www.lac.ox.ac.uk/sites/default/files/lac/documents/media/ karina20kuschnir2064.pdf

Lago, C. (2007). Antropologia e Jornalismo: uma questão de método. In C. Lago \& M. Benetti (Eds.), Metodologia da Pesquisa em Jornalismo (pp.48-66). Petrópolis/RJ: Vozes.

Leston-Bandeira, C. (2014). The Pursuit of Legitimacy as a Key Driver for Public Engagement: The Case of the European Parliament. Parliamentary Affairs, 67(2), 415-436. DOI: 10.1093/pa/gss050

Leston-Bandeira, C. (2016). Why Symbolic Representation Frames Parliamentary Public Engagement. The British Journal of Politics and International Relations, 18(2), 498-516. DOI: $10.1177 / 1369148115615029$

Merriam, S. B., \& Grenier R. S. (2019). Qualitative research in practice. Examples for discussion and analysis ( $2^{\text {nd }}$ ed.). San Francisco: JosseyBass.

Morley, D., \& Silverstone, R. (1993). Comunicación y contexto: la perspectiva etnográfica en los sondeos de opinión. In K. B. Jensen \& N. W Jankowski (Eds.), Metodologías cualitativas de investigación en comunicación de masas (pp.181-196). Barcelona: Bosch Comunicación.

Neveu, E. (2006). Sociologia do jornalismo. São Paulo: Edições Loyola.

Newcomb, H. M. (1993). La creación del drama televisivo. In K. B. Jensen \& N.W. Jankowski (Eds.), Metodologías cualitativas de investigación en comunicación de masas (pp.117-134). Barcelona: Bosch Comunicación.

Nunez, S. (2020). Doze anos de multimídia: convergência e engajamento público no Portal Senado Notícias [master thesis, Centro de Formação, Treinamento e Aperfeiçoamento da Câmara dos Deputados - Cefor]. Banco de TCCs da Câmara dos Deputados.

Peirano, M.(2014). Etnografia nãoé método. Horizontes Antropológicos, 20(42), 377-391. DOI: 10.1590/S0104-71832014000200015

Queiroz, D. (2007). Jornalismo institucional nas TVs legislativas. Os casos do Brasil e do México [master thesis, Universidade de Brasília]. Repositório Institucional da UNB.

Robinson, S. \& Anderson, C. W. (2020). Network Ethnography in Journalism Studies: A Mixed-Method Approach to Studying 
Media Ecologies. Journalism Studies, 21(7), 984-1001. DOI: $10.1080 / 1461670 X .2020 .1720519$

Sant'Anna, F. (2008). Mídia das fontes. O difusor do jornalismo corporativo. Brasília: Casa das Musas.

Schlesinger, P. (1978). Putting 'Reality' Together: BBC News. London: Constable.

Schlesinger, P. (2015). On the vagaries of production research. In C. Paterson, D. Lee, A. Saha \& A. Zoellner (Eds.), Advancing Media Production: Research Shifting Sites, Methods, and Politics (pp.20-37). London: Palgrave MacMillan.

Stewart, H., Gapp, R., \& Harwood, I. (2017). Exploring the alchemy of qualitative management research: seeking trustworthiness, credibility and rigor through crystallization. The Qualitative Report, 1(22), 1-19. DOI: $10.46743 / 2160-3715 / 2017.2604$

Traquina, N. (2001). O estudo do jornalismo no século XX. São Leopoldo, RS: Unisinos.

Travancas, I. (1993). O mundo dos jornalistas. São Paulo: Summus.

Travancas, I. (2010). An Ethnography of Journalistic Production: case studies of the Brazilian Press. Brazilian Journalism Research, 6(2), 82-102. DOI: 10.25200/BJR.v6n2.2010.19

Tuchman, G. (1983). La producción de la noticia. Estudio sobre la construcción de la realidad. Barcelona: Gustavo Gili.

Tuchman, G. (1993). A objectividade como ritual estratégico: uma análise das noções de objectividade dos jornalistas. In N. Traquina (Ed.), Jornalismo: questões, teorias e estórias (pp.74-90). Lisboa: Vega Ltda.

Urbinati, N. (2006). O que torna a representação democrática? Lua Nova, (67), 191-228. DOI: 10.1590/S0102-64452006000200007

Velho, G. (1981). Observando o familiar. In G. Velho (Ed.), Individualismo e cultura. Notas para uma Antropologia da sociedade contemporânea (pp.121-132). Rio de Janeiro: Zahar.

Wahl-Jorgensen, K. (2010). News production, Ethnography and Power: on the challenges of Newsroom-Centricity. In E. Bird (Ed.), The Anthropology of News and Journalism. Global Perspectives (pp.2134). Bloomington: Indiana University Press.

Wolf, M. (1995). Teorias da Comunicação. Lisboa: Editorial Presença.

Zémor, P. (2009). Como anda a comunicação pública? Revista do Serviço Público, 60(2), 189-195. DOI: 10.21874/rsp.v60i2.21 
CRISTIANE BRUM BERNARDES. Holds a PhD in Political Science (IESP/UERJ). She is a professor of the Professional Master's Degree in Legislative Branch at CEFOR (Chamber of Deputies). Member of the INCT in Digital Democracy (INCT-DD). Research associate for the Department of Anthropology and Sociology at SOAS (University of London), the Center for Democratic Engagement (University of Leeds) and the Laboratory for Ethnography of Institutions and Power Practices (UnB). Email: cris.brum@gmail.com

SARAH NUNEZ. Holds a Master's Degree in Legislative Branch from CEFOR (Chamber of Deputies). Specialist in Public Management, National School of Public Administration (Enap). She was editor-in-chief of the Portal Senado Notícias from 2017 to 2020. She has written a master's thesis and is an author of many articles in the areas of public and institutional communication, public engagement, digital journalism, and strategic communication management in the public sector. E-mail: sarahnunezanalista@gmail.com

TRANSLATED BY: LEE SHARP

Three reviews used in the evaluation of this article can be accessed at: https://osf.io/7wf8q, https://osf.io/zyvm7 and https:// osf.io/q8hz6 | Following BJR's open science policy, the reviewers authorized this publication and the disclosure of his/her names. 